\title{
Biogeochemical recuperation of lowland tropical forest during succession
}

\author{
Benjamin W. Sullivan id,${ }^{1,9}$ Rachel L. Nifong, ${ }^{2}$ Megan K. Nasto, ${ }^{3}$ Silvia Alvarez-Clare, ${ }^{4}$ Camie M. Dencker, ${ }^{1}$ \\ Fiona M. Soper id ${ }^{5}$ Kevin T. Shoemaker, ${ }^{1}$ F. Yoko Ishida, ${ }^{6}$ Joana Zaragoza-Castells, ${ }^{7}$ Eric A. Davidson, ${ }^{8}$ and \\ Cory C. Cleveland iD 5 \\ ${ }^{1}$ Department of Natural Resources \& Environmental Science and The Global Water Center, University of Nevada, Reno, Nevada 89557 USA \\ ${ }^{2}$ Water Quality and Ecology Research Unit, National Sedimentation Laboratory, United States Department of Agriculture, Agricultural \\ Research Service, Oxford, Mississippi 38655 USA \\ ${ }^{3}$ Department of Biology and The Ecology Center, Utah State University, Logan, Utah 84322 USA \\ ${ }^{4}$ Center for Tree Science, The Morton Arboretum, Lisle, Illinois 60532 USA \\ ${ }^{5}$ Department of Ecosystem and Conservation Sciences, University of Montana, Missoula, Montana 59812 USA \\ ${ }^{6}$ Centre for Tropical, Environmental and Sustainability Sciences, College of Science and Engineering, James Cook University, Cairns, \\ Queensland 4870 Australia \\ ${ }^{7}$ Department of Geography, College of Life and Environmental Sciences, University of Exeter, Exeter EX4 4RJ United Kingdom \\ ${ }^{8}$ Appalachian Laboratory, University of Maryland Center for Environmental Science, Frostburg, \\ Maryland 21532 USA
}

Citation: Sullivan, B. W., R. L. Nifong, M. K. Nasto, S. Alvarez-Clare, C. M. Dencker, F. M. Soper, K. T. Shoemaker, F. Y. Ishida, J. Zaragoza-Castells, E. A. Davidson, and C. C. Cleveland. 2019. Biogeochemical recuperation of lowland tropical forest during succession. Ecology 100(4):e02641. 10.1002/ecy.2641

Abstract. High rates of land conversion and land use change have vastly increased the proportion of secondary forest in the lowland tropics relative to mature forest. As secondary forests recover following abandonment, nitrogen $(\mathrm{N})$ and phosphorus $(\mathrm{P})$ must be present in sufficient quantities to sustain high rates of net primary production and to replenish the nutrients lost during land use prior to secondary forest establishment. Biogeochemical theory and results from individual studies suggest that $\mathrm{N}$ can recuperate during secondary forest recovery, especially relative to $\mathrm{P}$. Here, we synthesized 23 metrics of $\mathrm{N}$ and $\mathrm{P}$ in soil and plants from 45 secondary forest chronosequences located in the wet tropics to empirically explore (1) whether there is a consistent change in nutrients and nutrient cycling processes during secondary succession in the biome; (2) which metrics of $\mathrm{N}$ and $\mathrm{P}$ in soil and plants recuperate most consistently; (3) if the recuperation of nutrients during succession approaches similar nutrient concentrations and fluxes as those in mature forest in $\sim 100 \mathrm{yr}$ following the initiation of succession; and (4) whether site characteristics, including disturbance history, climate, and soil order are significantly related to nutrient recuperation. During secondary forest succession, nine metrics of $\mathrm{N}$ and/or $\mathrm{P}$ cycling changed consistently and substantially. In most sites, $\mathrm{N}$ concentrations and fluxes in both plants and soil increased during secondary succession, and total $\mathrm{P}$ concentrations increased in surface soil. Changes in nutrient concentrations and nutrient cycling processes during secondary succession were similar whether mature forest was included or excluded from the analysis, indicating that nutrient recuperation in secondary forest leads to biogeochemical conditions that are similar to those of mature forest. Further, of the $\mathrm{N}$ and $\mathrm{P}$ metrics that recuperated, only soil total $\mathrm{P}$ and foliar $\delta^{15} \mathrm{~N}$ were strongly influenced by site characteristics like climate, soils, or disturbance history. Predictable nutrient recuperation across a diverse and productive ecosystem may support future forest growth and could provide a means to quantify successful restoration of ecosystem function in secondary tropical forest beyond biomass or species composition.

Key words: disturbance; nitrogen; nutrient cycling; phosphorus; plants; soil.

Manuscript received 28 June 2018; revised 10 November 2018; accepted 7 January 2019. Corresponding Editor: Hugh Henry.

${ }^{9}$ E-mail: bsullivan@cabnr.unr.edu 


\section{INTRODUCTION}

Disturbance and land use change have fundamentally altered the tropical forest biome. Between 2000 and 2012, the tropics experienced the highest rates of gross forest loss $\left(1.11 \times 10^{6} \mathrm{~km}^{2}\right)$ and gain $\left(0.25 \times 10^{6} \mathrm{~km}^{2}\right)$ of any region on Earth (Hansen et al. 2013). Presently, secondary forest may represent $\sim 30 \%$ of all tropical forest (Pan et al. 2011), and the tropics have the most dynamic rates of land use change relative to other forested biomes (FAO 2016). If such trends continue into the future, the significance of the extent and function of secondary forest relative to mature forest will only continue to increase (Chazdon 2014).

The global carbon (C) and water cycles are tightly linked to tropical land use dynamics (Ramankutty et al. 2007, Lawrence and Vandecar 2015). Lowland tropical forest has some of the highest rates of net primary production (NPP) on Earth, and changes in tropical forest NPP may have consequences for the terrestrial C sink and biogeochemical cycles (Batterman et al. 2013, Cleveland et al. 2015, Liu et al. 2015). Carbon cycling is intricately tied to the availability of nutrients like nitrogen (N) and phosphorus (P) (Wieder et al. 2015). Though deforestation generally reduces the nutrient capital available for future productivity (McGrath et al. 2001), secondary tropical forest often shows both higher rates of NPP and higher nutrient demand than mature forest (Batterman et al. 2013). While NPP in secondary forests is apparently resilient to disturbance (Poorter et al. 2016), other important forest characteristics, such as species composition and stand structure, may be unpredictable during secondary succession (Norden et al. 2015). Nutrient availability may constrain the recovery of the $\mathrm{C}$ cycle after disturbance and during secondary succession, but it is unclear whether biogeochemical recuperation following disturbance may be common throughout the tropics, whether only one or both of the $\mathrm{N}$ or $\mathrm{P}$ cycles recuperate, if state factors or disturbance history influence recuperation, or if recuperation eventually leads to biogeochemical conditions that are similar to those that would be found in mature forest had secondary forest not replaced it.

Decades of biogeochemical theory (e.g., Walker and Syers 1976, Peltzer et al. 2010) and experimental and observational evidence (e.g., Hedin et al. 2003, McGroddy et al. 2004, Cleveland and Townsend 2006, Houlton et al. 2006) suggest that soil nutrients predominantly derived from rock weathering (like P) limit ecosystem functions in undisturbed mature tropical forest growing on highly weathered soils more often than N. Disturbance and land use change may profoundly alter the relative availability of soil nutrients and rates of nutrient cycling in the lowland tropics (McGrath et al. 2001, Neill et al. 2001). For example, forest harvest and cultivation can deplete $\mathrm{N}$ stocks in organic matter via oxidation, volatilization, pyrogenic emissions, biomass removal, and leaching, and more intensive land use can increase rates of $\mathrm{N}$ loss and inhibit forest recovery (Jordan et al. 1983, Uhl 1987, Davidson et al. 2004). Yet, in many cases, rapid regeneration of secondary tropical forest biomass (Chazdon 2014, Poorter et al. 2016) can be associated with changes in ecosystem functions like NPP and decomposition (Lohbeck et al. 2015). One study in the Amazon Basin found that $\mathrm{N}$ pools and fluxes were low relative to $\mathrm{P}$ immediately after agricultural abandonment, but recuperated during secondary succession such that $\mathrm{N}$ became more available relative to $\mathrm{P}$, consistent with the biogeochemical theory of $\mathrm{P}$ limitation in mature tropical forest (Davidson et al. 2007). In other Amazonian sites, $\mathrm{N}$ recuperation may occur rapidly after the initiation of secondary succession (Winbourne et al. 2018). Similar evidence from other studies has yielded a general conceptual theory that $\mathrm{N}$ availability recovers during secondary succession, but total $\mathrm{P}$ availability does not change substantially (Powers and Marín-Spiotta 2017). However, a recent global meta-analysis of soil $P$ concentrations and stocks suggested that, in the tropics, soil available $\mathrm{P}$ pools may increase during succession while soil total P may decrease (Deng et al. 2017). While increasing nutrient stocks in biomass are intuitively associated with increasing plant biomass, the fact that wholeecosystem nutrient stocks, including soil nutrients, may also recover as secondary tropical forest biomass recovers is perplexing. Longstanding theory from temperate ecosystems suggests that regenerating forests should obtain limiting nutrients for plant growth by reducing nutrients in the soil (Odum 1969, Vitousek and Reiners 1975). Secondary tropical forest may avoid this period of resource limitation induced via rapid biomass growth and nutrient retention in biomass if nutrient availability in the soil recuperates commensurately with nutrient accumulation in plant biomass.

What mechanisms would allow for $\mathrm{N}$ (or possibly $\mathrm{P}$ ) cycles to recuperate in lowland wet tropical forest? Biological dinitrogen $\left(\mathrm{N}_{2}\right)$ fixation rates within secondary forest, sometimes in excess of $10 \mathrm{~kg} \mathrm{~N} \cdot \mathrm{ha}^{-1} \cdot \mathrm{yr}^{-1}$, provide one likely mechanism that could enhance soil and plant N stocks (Batterman et al. 2013, Sullivan et al. 2014, Davidson et al. 2018), especially relative to P. By this logic, $\mathrm{N}$ accumulation could depend on plant species or traits (e.g., legumes are not equally abundant in all tropical forests (Losos and Leigh 2004), or the relationship between edaphic and climatic conditions and nutrient losses. However, while $\mathrm{N}$ accumulation via $\mathrm{N}_{2}$ fixation has long been posited in secondary tropical forest (e.g., Jenny 1950), a recent synthesis demonstrated that legumes may have less of an influence on secondary forest characteristics relative to non-legumes in wet tropical forest than dry tropical forest (Gei et al. 2018). In contrast to $\mathrm{N}$, the ecosystem $\mathrm{P}$ capital should generally decline over long time scales, as rock-derived nutrients are at their maximum early in ecosystem development (Walker and Syers 1976, Peltzer et al. 2010). The extent to which $\mathrm{P}$ might change during secondary succession is less predictable (Peltzer et al. 2010). Mechanisms of $\mathrm{P}$ 
accumulation in biomass and surface soils could include movement of $\mathrm{P}$ from deep within the soil profile to shallow soils by plants (Jobbágy and Jackson 2001, Nepstad et al. 2001, MacDonald et al. 2012), trapping of dustborne $\mathrm{P}$ resulting from growing vegetation biomass and increased canopy roughness (Powers and Marín-Spiotta 2017), or changing microclimatic conditions that favor high rates of $\mathrm{P}$ mineralization (Deng et al. 2017).

The biological, chemical, and biophysical diversity of the tropics (Townsend et al. 2008, Porder and Hilley 2011) also makes it challenging to predict whether shifts in nutrient availability and biogeochemical recuperation during forest succession at any one site can be generalized across the biome. Over short distances within a lowland forest, state factors can drive substantial changes in nutrient availability and ecosystem processes (Osborne et al. 2017). In fact, a recent analysis suggested that biomass recovery in the Brazilian Amazon may depend on both forest disturbance history and the initial availability of soil nutrients (Nagy et al. 2017). High rates of mature forest loss and secondary forest gain in the lowland tropics (Hansen et al. 2013) create a need to quantitatively assess whether or not biogeochemical recuperation is a consistent phenomenon during secondary succession, and what aspects of biogeochemical change are most consistent relative to others (e.g., $\mathrm{N}$ relative to $\mathrm{P}$ ).

To address this question, we synthesized previously published results from 45 secondary forest chronosequences in the lowland tropics to estimate the rate of change per year of succession for as many metrics of $\mathrm{N}$ and $\mathrm{P}$ in soil and plants as we could identify in the literature. We compiled a total of 23 metrics of $\mathrm{N}$ and $\mathrm{P}$ including 12 soil- and 11 plant-based metrics. Focusing on rates of change through time allowed us to compare changes in $\mathrm{N}$ and $\mathrm{P}$ availability among sites despite the fact that studies measured succession over different time scales, used different methods, and often reported nutrient pools and fluxes in different units. Next, we explored whether the trajectory of biogeochemical recuperation during secondary succession leads to nutrient conditions similar to those found in mature forest, or whether the trajectory of secondary forest recuperation leads to an alternative biogeochemical state. Finally, we evaluated whether patterns of biogeochemical recuperation are common among sites in the lowland tropics, or if disturbance history, climate, and soils resulted in variation of the rate of change in nutrient pools and fluxes during secondary succession.

We focused our analysis on changes in soil and plant nutrient concentrations and nutrient cycling rather than nutrient stocks for several reasons. First, studies most often report $\mathrm{C}$ and nutrient pools on a percent or per mass basis and rarely report detailed bulk density measurements needed to convert mass-based to area-based estimates. Instead, we focused on changes in rates of $\mathrm{N}$ and $\mathrm{P}$ availability and cycling through time. Beyond the paucity of data, in some cases, total soil nutrient stocks may not be representative of the size of the biologically active fraction of nutrients available for plant or microbial use. Additionally, changes in nutrient stocks may be inferred from changes in nutrients while making some simple assumptions about changes in soil bulk density or plant biomass. Aboveground, a trend of increasing nutrient concentrations in plant tissues, combined with increasing vegetation biomass during secondary succession (Norden et al. 2015, Poorter et al. 2016), would mean nutrient stocks increase faster than nutrient concentrations. Belowground, changes in soil nutrient stocks during secondary succession would be consistent with changes in soil nutrient concentrations as long as there was little change in soil bulk density or if the change in bulk density during succession was in the same direction as the change in soil nutrient concentration. Therefore, we assessed recuperation as a change in available nutrients and nutrient cycling processes during succession that provide resources for plant growth and microbial activity, allowing secondary forest to become biogeochemically similar to mature forest.

Finally, chronosequence studies, which depend on space-for-time substitutions, are based on often untested assumptions: that sites differ only in their time since disturbance and that, given time, secondary forests will experience a similar range of climatic conditions as those already experienced by mature forest sites (Jenny 1941, Johnson and Miyanishi 2008, Walker et al. 2010). The studies utilized here are no different, but the inferences made based on chronosequences are still useful, especially when considering how differences among studies may inform successional trajectories (Mora et al. 2015).

\section{Methods}

We synthesized data from peer-reviewed literature to assess changes in soil and plant nutrients through secondary succession. We used the Thomson-Reuters search engine "Web of Science" to identify published, peer reviewed studies that included the search terms "tropic*," "succession," and either "nitrogen" or "phosphorus." Of the resulting studies, we narrowed our search to include only studies that measured plant or soil $\mathrm{N}$ or $\mathrm{P}$ availability or a nutrient flux. Studies included in the analysis were located between $23.5^{\circ} \mathrm{N}$ and $23.5^{\circ} \mathrm{S}$ latitude, had elevations below $1,000 \mathrm{~m}$, had mean annual precipitation $>1,275 \mathrm{~mm} / \mathrm{yr}$, had mean annual temperatures $>20^{\circ} \mathrm{C}$, and were either moist or wet lowland forests. These thresholds are consistent with other syntheses of primary productivity and biogeochemistry in lowland moist and wet tropical forest, where productivity and decomposition, among other ecosystem processes, function differently than montane or drier tropical forest (Holdridge et al. 1971, Cleveland et al. 2011, Taylor et al. 2017). To standardize among studies, we used values from surface soil $(0-20 \mathrm{~cm}$, maximum) only. Each study had to include at least one successional site and at least one mature, reference condition forest site because two sites were necessary to assess a rate of

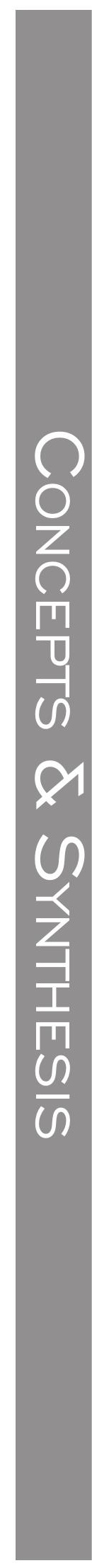


change during succession. We added studies to our synthesis if they were cited in one of the original studies identified in our Web of Science search. The resulting studies yielded 45 individual chronosequences. The associated metrics of $\mathrm{N}$ and/or $\mathrm{P}$ availability and ancillary climate and edaphic data obtained from those studies are described in Data S1. The studies associated with each chronosequence are reported in Appendix S1. There were nine studies for which either temperature or precipitation measurements were not reported; data were collected from the literature for the same time period and location to supplement the original data (Appendix S1). When data were presented as figures, we obtained the data using the digitizing software Engauge for Mac OSX (available online). ${ }^{10}$

We identified a total of 23 different soil or plant pools of $\mathrm{N}$ and $\mathrm{P}$, which we generally refer to as nutrient ( $\mathrm{N}$ or P) metrics (Table 1). Soil nutrient concentrations include biologically available pools (such as ammonium, nitrate, inorganic $\mathrm{N}$, and labile $\mathrm{P}$ ) or pools that are considered less biologically available (such as soil total $\mathrm{N}$ and $\mathrm{P}$ ). Nutrient fluxes, such as mineralization, nitrification, and $\mathrm{N}$ gas losses via nitrification or denitrification (including $\mathrm{N}_{2} \mathrm{O}, \mathrm{N}_{2}$, and $\mathrm{NO}_{\mathrm{x}}$ gas), indicate the availability of nutrient substrates for microbial transformation (Hart et al. 1994). Plant concentrations of $\mathrm{N}$ and $\mathrm{P}$ represent unavailable organic forms of $\mathrm{N}$ and $\mathrm{P}$, but also nutrients that were at one time available and absorbed by the plant, and nutrient capital that will eventually become available again after plant mortality. Therefore, these metrics represent the capital of $\mathrm{N}$ and $\mathrm{P}$ on site during succession. Hence, for simplicity, we refer to the metrics as indicative of nutrient availability, even when referring to unavailable forms of a nutrient.

Following other studies that sought to analyze successional patterns among chronosequences (e.g., Vitousek et al. 1989), we avoided categorizing successional stages, and instead used "time since disturbance" to determine successional status. This approach allowed us to focus our analysis on rates of change of nutrient metrics rather than categorical or binomial responses to disturbance or forest growth. All studies reported time since disturbance for successional forests, but if a study indicated a range of ages (e.g., an age class), we used the mean of that range as the time since disturbance. Likewise, if a study only reported a maximum or minimum value for a forest age class (e.g., $<2 \mathrm{yr}$ ), we used the reported value (i.e., $2 \mathrm{yr}$ ). Most studies included mature forests as a reference condition, but of these, only a handful reported ages of mature forest. When reported, we used the age of the mature forest as an indicator of time since last disturbance, assuming that the authors had information from local peoples or written records of land use to inform these estimates. Several studies located in China described $400 \mathrm{yr}$ as the approximate number of years since last disturbance (Mo et al. 2003, Huang et al.

\footnotetext{
${ }^{10} \mathrm{http}: / /$ markummitchell.github.io/engauge-digitizer/
}

TABLE 1. Generalized linear mixed model (GLMM) parameter coefficient and standard errors of 23 metrics of soil and plant nitrogen and phosphorus change during secondary tropical forest succession.

\begin{tabular}{|c|c|c|c|}
\hline Metric & $\begin{array}{c}\text { Fixed effect } \\
\text { model coefficient }\end{array}$ & SE & $P$ \\
\hline \multicolumn{4}{|l|}{ Soil } \\
\hline Ammonium & -0.05 & 0.04 & 0.167 \\
\hline$\delta^{15} \mathrm{~N}$ & 0.02 & 0.08 & 0.803 \\
\hline Inorganic $N$ & 0.12 & 0.04 & 0.003 \\
\hline Labile $P$ & 0.10 & 0.08 & 0.243 \\
\hline$N$ gas loss & 0.24 & 0.12 & 0.051 \\
\hline $\mathrm{N}$ mineralization & 0.02 & 0.04 & 0.568 \\
\hline Nitrate & 0.28 & 0.10 & 0.005 \\
\hline Nitrate:ammonium & -0.04 & 0.17 & 0.830 \\
\hline Nitrification & 0.12 & 0.12 & 0.318 \\
\hline $\mathrm{N}: \mathrm{P}$ & -0.02 & 0.06 & 0.79 \\
\hline Total N & 0.23 & 0.10 & 0.042 \\
\hline Total P & 0.03 & 0.01 & 0.0107 \\
\hline \multicolumn{4}{|l|}{ Plant } \\
\hline Foliar $\delta^{15} N$ & 0.67 & 0.35 & 0.076 \\
\hline Foliar N & -0.61 & 1.82 & 0.755 \\
\hline Foliar N:P & 0.13 & 0.04 & 0.003 \\
\hline Foliar $P$ & -0.41 & 0.35 & 0.241 \\
\hline Litter N:P & 2.64 & 4.43 & 0.591 \\
\hline Litter mass: $N$ & -0.03 & 0.01 & 0.007 \\
\hline Litter $\mathrm{N}$ & NA & NA & \\
\hline Litter P & NA & NA & \\
\hline Root $N$ & 3.28 & 1.30 & 0.073 \\
\hline Root N:P & NA & NA & \\
\hline Root P & NA & NA & \\
\hline
\end{tabular}

Notes: These parameter estimates are not mathematically equivalent to a slope of a simple linear regression due to the underlying structure of the GLMM and the scaling of years. Italic typeface indicates metrics where the standard error of the estimate was smaller than the estimate. NA denotes metrics for which a sufficient sample size was not available for a generalized mixed model to converge.

2011, 2012, 2013). However, because of the difficulty of knowing land use histories greater than $\sim 80 \mathrm{yr}$ in many other parts of the tropics, most studies did not describe years elapsed since disturbance in mature forest. In fact, the concept of a mature forest "age" may be misleading: species turnover and individual tree replacement can lead to disturbance within a mature forest (Clark 1996). Given our focus on time since disturbance and the contrasting use of "mature forest" as a categorical descriptor of a reference condition in most published studies, we chose to assign a "time since disturbance" for mature forest in those cases where it was not reported. Gap dynamics theory (e.g., Hartshorn 1980) suggests that a given plot of mature tropical forest may be, on average, $\sim 75-150$ yr old. While individual trees may exceed that age within a mature forest, the forest itself has large areas that may have much younger trees due to forest dynamics. Therefore, we designated all mature forest sites of unknown or unspecified age as $100 \mathrm{yr}$ old to recognize the important role of gap dynamics in species 
composition and biogeochemical function within tropical forest. We do not imply that all mature forest in the lowland tropics are only $100 \mathrm{yr}$ old, rather, we assign that as a time since disturbance that can be associated with mature forest, which experiences gap dynamics as a matter of course.

\section{Statistical analyses}

Our objective was to assess trends in soil and plant nutrient pools and fluxes through time in both literature-derived measurements and field measurements. First, we used generalized mixed models (GLMMs) using the glmer function in the lme4 package (Bates et al. 2015) in R ( $\mathrm{R}$ Core Team 2017) in which we used a scaled forest age since disturbance as a fixed effect and study (the individual chronosequence) as a random variable, allowing the intercept and parameter coefficient to vary for each study. We used GLMMs for their flexibility in analyzing patterns despite non-normally distributed residuals of the data. Similarly, by including "study" as a random variable, we acknowledged observations within a study were more related than those across studies and thus we were enabling the model to account for site-specific contingencies and methodological differences without letting these differences affect the ability of the model to find a general pattern. This model structure allowed for different relationships between explanatory and response variables for each study, accounting for site differences and allowing pooled observations across studies to be more generalizable. Scaled ages were calculated using the "scale" function in R, which subtracts the mean and divides by the standard error, and was used in order to standardize the data and reduce orders of magnitude variation in forest age while still representing the relative differences among sites. Ages were centered by subtracting the median and dividing by the standard deviation. We scaled ages to improve model convergence; ages spanned two orders of magnitude. We used this statistical analysis to infer change through time. Four metrics (root N:P, root P, litter P, and litter N) had insufficient data for model convergence. Models fit a log-normal error distribution to the soil and plant nutrient metrics with the exception of root N, litter N:P, foliar $\mathrm{N}$, and foliar $\delta^{15} \mathrm{~N}$, which were normally distributed (and hence the GLMM became a linear mixed model; distributions were determined using the descdist function in the fitdistrplus package in R; Delignette-Muller and Dutang 2015). We present change through time of untransformed soil pools and fluxes and plant pools for ease of interpretation, but show $\ln$-transformed forest ages in order to better depict important changes happening early in succession.

Next, we calculated the linear rate of change (slope) of each metric that changed through time (years) following disturbance using simple linear regression for each variable for each study in the analysis, and slopes were used to determine if the rates of change were similar when mature forest was excluded from the plots using a Mann-Whitney $U$ test. As above, non-linear response variables were $\ln$-transformed prior to slope analysis. Slopes, as depicted in our figures and described in the manuscript, represent an average rate of change over the successional period. When rates of change were non-linear (addressed statistically using GLMMs), actual rates of change of a non-linear nutrient metric may be greater or less than the average rate of change depicted in our figures during periods of secondary succession.

Then, we ran a different set of GLMMs from those above (to improve model convergence) to assess how site characteristics, including temperature, precipitation, soil order and disturbance history, influenced each metric of nutrient availability that significantly differed during secondary succession in the GLMMs above. There were two steps in this analysis, which again used a model structure in which study was included as a random intercept. Initially, we built a full model, in which all site characteristics above were included. However, because we often had insufficient data coverage to allow this complex model structure to converge, we then ran a series of models in which individual site characteristics were fixed effects and study was a random effect.

\section{Results}

Our results demonstrate that biogeochemical recuperation in secondary tropical forest is common across the lowland tropical region, despite considerable biological and biogeochemical heterogeneity among sites. The sites in our database spanned all continents located within the tropics, although most sites were located in the Neotropics, and included only eight sites in Asia and northern Australia and one site in Africa (Fig. 1). The soil orders represented were predominantly $(87 \%)$ classified as Ultisols or Oxisols (Soil Survey Staff 2014) or their analogs in other classification systems, but sites with Inceptisols, Mollisols, or Spodosols were also in the database. In the studies that reported land use histories, pasture and cultivation were the most common reason why mature forest was initially harvested, followed by swidden agriculture and timber extraction (Data S1).

Of the 23 metrics of nutrient availability, nine showed evidence of recuperation during secondary succession (Table 1; Fig. 2). Of the 12 soil $\mathrm{N}$ and $\mathrm{P}$ pools and fluxes that we analyzed, five increased with secondary forest age: soil total $\mathrm{N}(P=0.042)$, total $\mathrm{P}(P=0.011)$, nitrate $\left(\mathrm{NO}_{3}^{-}\right)$concentration $(P=0.005)$, total available $\mathrm{N}$ (calculated as $\mathrm{NH}_{4}^{+}+\mathrm{NO}_{3}^{-} ; P=0.003$ ), and $\mathrm{N}$ gas loss $(P=0.051$; Fig. 2). For the 11 plant-based metrics, three were positively related to secondary forest age: root $\mathrm{N}$ $(P=0.073)$, foliar $\mathrm{N}: \mathrm{P}(P=0.003)$, and foliar $\delta^{15} \mathrm{~N}$ $(P=0.076$; Fig. 2). A fourth, litter mass: N, was negatively related to secondary forest age $(P=0.007$; Fig. 2$)$, consistent with increasing $\mathrm{N}$ during succession. We lacked sufficient data to analyze the remaining four plant metrics (root N:P, root $\mathrm{P}$, litter $\mathrm{P}$, and litter $\mathrm{N}$ ). 

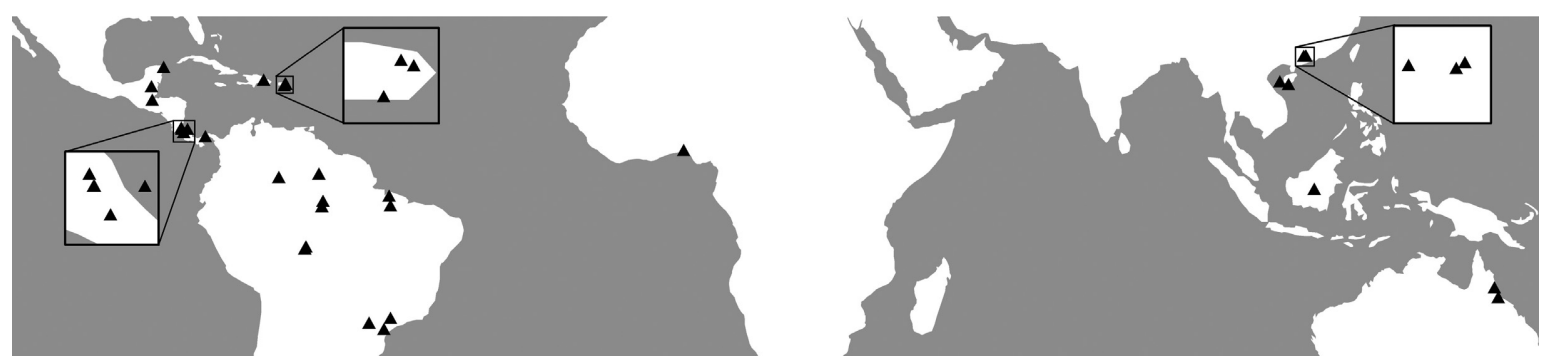

FIG. 1. Map of locations of studies within the database.
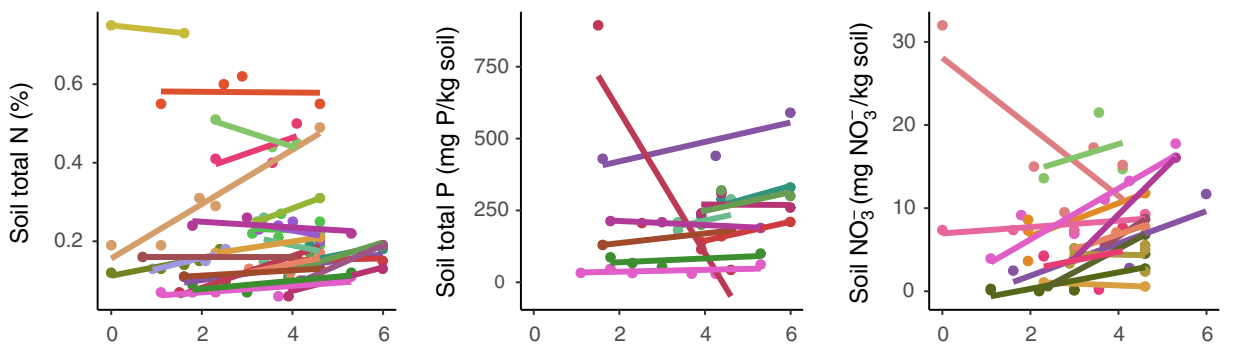

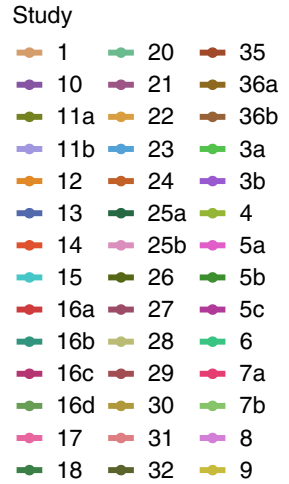
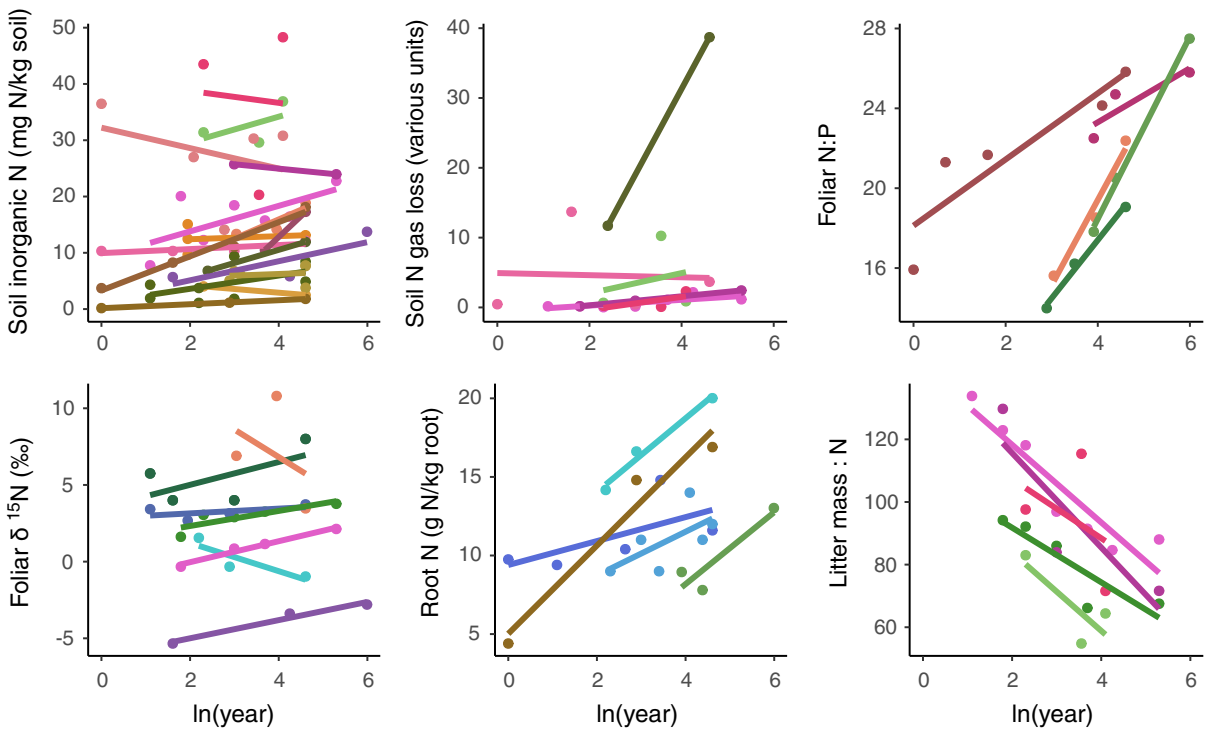

FIG. 2. Individual rates of change through time of the nine metrics of soil and plant nitrogen $(\mathrm{N})$ and phosphorus $(\mathrm{P})$ from individual studies. The numbers in the legend of each panel correspond to individual studies as listed in $\mathrm{Data}^{\mathrm{S}}$. $\mathrm{NO}_{3}^{-}$is soil nitrate concentrations.

Most individual studies showed increasing trends in nutrient availability during secondary succession (Figs. 2, 3). Changes in nutrient metrics during succession among sites were generally similar during secondary succession with the exception of soil P (Fig. 2). However, the variance of the rate of change of soil total $\mathrm{P}$ during secondary succession was heavily biased by a 20 fold decline in soil P in a single study ( 894 to $43 \mathrm{mg} / \mathrm{kg}$; Long et al. 2012). Though shown in figures, data from this site were removed from statistical analyses because the 20-fold decrease in soil $\mathrm{P}$ was implausible without a major erosion event, yet the authors reported no additional site disturbance other than historic deforestation. The rate of nutrient change (e.g., soil total $\mathrm{N}$, $\mathrm{NO}_{3}^{-}, \mathrm{N}$ gas loss) associated with individual studies in Fig. 2 appears to change as much as soil total $\mathrm{P}$ in Long et al. (2012), but due to differences in $y$-axes the actual rates of change were much lower. Belowground, the number of positive rates of change exceeded negative rates of change for all metrics except soil $\mathrm{NH}_{4}^{+}$concentrations (Fig. 3). In addition, the direction of change of plant tissue nutrient concentrations was more variable than belowground, but generally trended toward greater $\mathrm{N}$ concentrations relative to $\mathrm{P}$ concentrations (Fig. 3). 


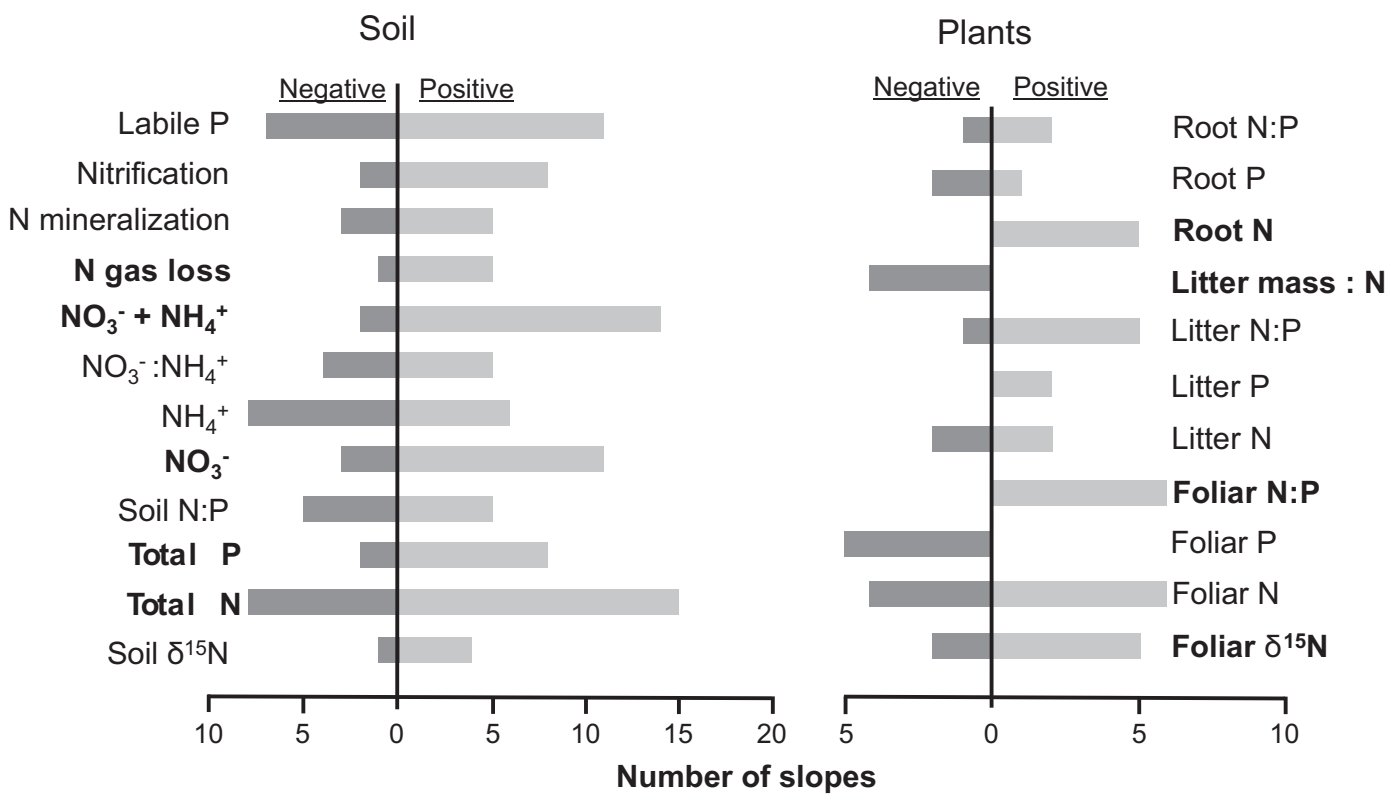

FIG. 3. Histograms depicting the number of positive and negative slopes of plant and soil nitrogen (N) and phosphorus (P) metrics during secondary succession in lowland tropical forest. Boldface text indicates the nine metrics of nutrient availability that changed significantly during secondary succession. Abbreviations are ammonium $\left(\mathrm{NH}_{4}^{+}\right)$, nitrate $\left(\mathrm{NO}_{3}^{-}\right)$, and the isotope ratio of $\mathrm{N}$ $\left(\delta^{15} \mathrm{~N}\right)$.

While there was strong evidence that, overall, soil total $\mathrm{N}$ increased during secondary succession $(P=0.042)$, initial soil $\mathrm{N}$ concentrations at the outset of succession influenced the trajectory of $\mathrm{N}$ recovery. Sites with high initial soil total $\mathrm{N}(>0.25 \%)$ generally lost $\mathrm{N}$ during secondary succession, whereas sites with low initial soil total $\mathrm{N}$ generally gained $\mathrm{N}$ during succession (MannWhitney $U$ test of slope differences $P=0.074$ ).

Nutrient recuperation patterns during secondary succession were not biased by including mature forest in our models. Eight of the nine recuperating soil and plant nutrient metrics had statistically similar rates of change during secondary succession whether we included or excluded mature forest from the analysis (Fig. 4). The only metric that was influenced by including (or excluding) mature forest from the analysis was litter mass: $\mathrm{N}$ $(P=0.036)$, and in that case, the exclusion of mature forest actually increased the estimated rate of decline in the litter mass: $\mathrm{N}$ ratio (Fig. 4).

Seven of the nine recuperating $\mathrm{N}$ and $\mathrm{P}$ metrics were largely consistent among studies despite considerable variability in site characteristics among study sites (Table 2). The two metrics that were most heavily influenced by site characteristics were soil total $\mathrm{P}$ and foliar $\delta^{15} \mathrm{~N}$ (Table 2). Soil total $\mathrm{P}$ was strongly influenced by mean annual precipitation $(P<0.01)$, disturbance type $(P<0.01)$, and soil order $(P<0.01 ;$ Fig. 5$)$. Foliar $\delta^{15} \mathrm{~N}$ was influenced by mean annual temperature $(P<0.01)$, disturbance type $(P<0.01)$, and soil order $(P<0.01$; Fig. 5). There was evidence that three other recuperating nutrients $\left(\mathrm{NO}_{3}^{-}\right.$, root $\mathrm{N}$, and foliar $\left.\mathrm{N}: \mathrm{P}\right)$ varied with one site characteristic $(P<0.01, P=0.03, P=0.03$, respectively; Table 2; Fig. 5). By contrast, soil total N, inorganic $\mathrm{N}$, soil $\mathrm{N}$ gas loss, and litter mass: $\mathrm{N}$ did not vary substantially with any site characteristics (Table 2).

\section{DisCusSion}

Individual studies of biogeochemical change after disturbance have shown that the $\mathrm{N}$ cycle is capable of recovery during secondary succession in tropical forest (e.g., Davidson et al. 2007). As a result, literature reviews have posited that biogeochemical recuperation may be common across the biome (Chazdon 2014, Powers and Marín-Spiotta 2017). Here, our results quantitatively establish that, in most cases, nine particular biogeochemical metrics related to both $\mathrm{N}$ and $\mathrm{P}$ usually recuperate in lowland tropical forests undergoing secondary succession. Biogeochemical recuperation of nutrient cycling may be a mechanism that allows secondary tropical forest biomass and composition to recover quickly following disturbance (e.g., Poorter et al. 2016).

Both theory and data suggest that biological $\mathrm{N}_{2}$ fixation provides ecosystems with a mechanism to quickly rebuild their $\mathrm{N}$ economies (Powers and Marín-Spiotta 2017). By contrast, because there is no $N_{2}$ fixation analogue for P, P concentrations should decline or remain relatively stable during secondary succession in tropical soils (Peltzer et al. 2010, Powers and Marín-Spiotta 2017). The increases in soil total $\mathrm{N}, \mathrm{NO}_{3}^{-}$concentration, inorganic $\mathrm{N}$ concentration $\left(\mathrm{NH}_{4}^{+}+\mathrm{NO}_{3}^{-}\right)$, and gaseous 
它 With 官 Without
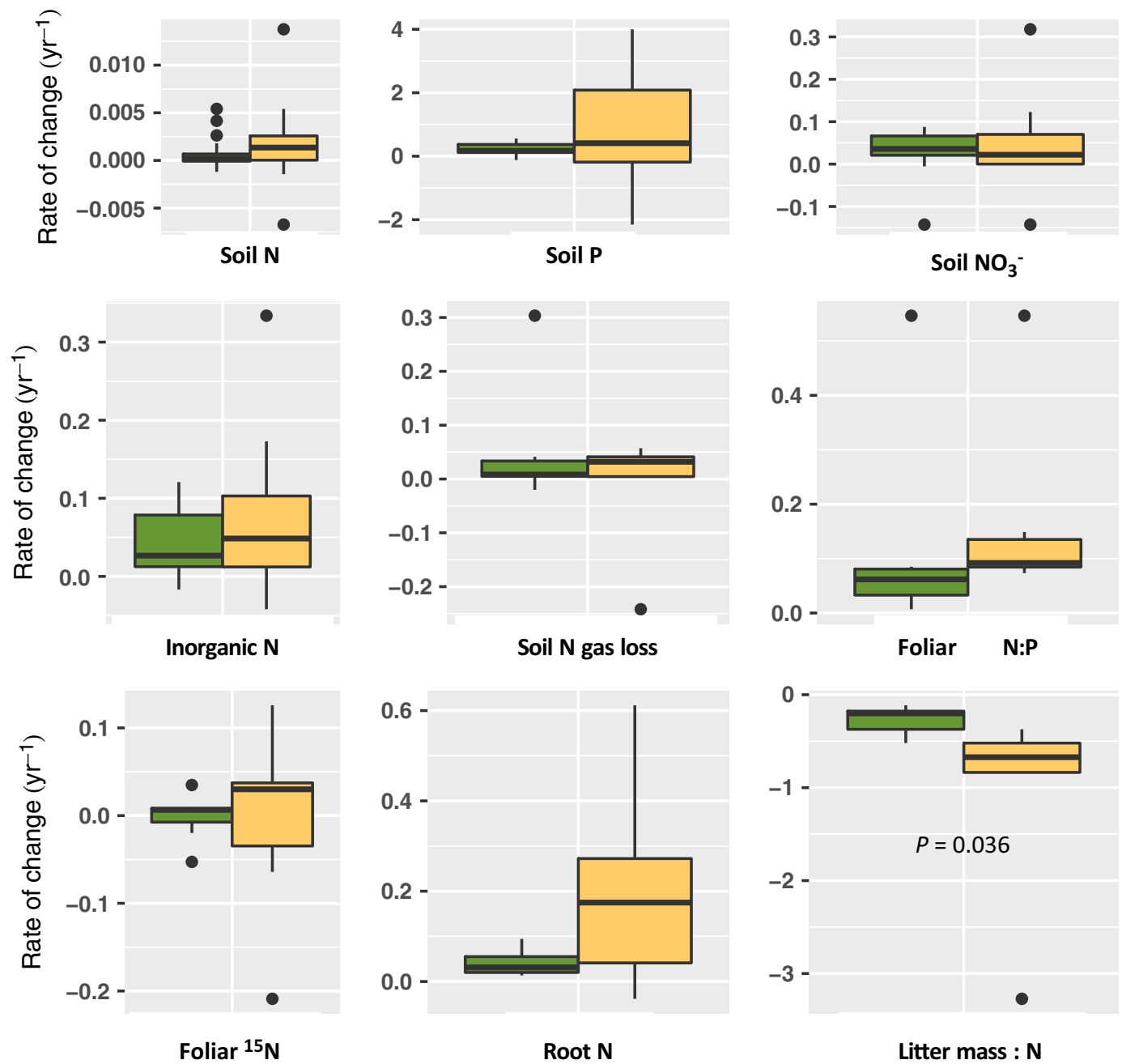

FIG. 4. Changes in nutrient cycling metrics including or excluding mature tropical forest sites. None of the nine metrics of nitrogen $(\mathrm{N})$ or phosphorus $(\mathrm{P})$ availability that changed during succession showed evidence that recuperation was caused by the inclusion of mature forest in our analysis. The one metric that did differ when including and excluding mature forest (litter mass: $\mathrm{N}$ ) actually showed a higher rate of $\mathrm{N}$ accumulation relative to litter mass when mature forest was excluded. Median comparisons were made with a Mann-Whitney $U$ test. These similar rates of change imply that the biogeochemical resilience apparent during succession was not the result of including mature forest in our analysis, or setting an age for mature forest that may have been artificially low $(100 \mathrm{yr})$. The box mid line represents the median; the box edges represent the 25 th and 75 th percentiles of the data. The upper whiskers are calculated as the smaller value between the maximum $y$-value or 1.5 times the interquartile range. The bottom whiskers are calculated as the larger value between the $y$-value and 1.5 times the interquartile range. $\mathrm{NO}_{3}^{-}$is soil nitrate concentrations.

$\mathrm{N}$ losses observed among sites were consistent with a model of increasing $\mathrm{N}$ availability during succession. However, increases in soil total $\mathrm{N}$ concentrations tended to be higher in sites with initially low soil total $\mathrm{N}$ concentrations, whereas sites with initially higher soil total $\mathrm{N}$ tended to gain $\mathrm{N}$ less quickly or even lose soil $\mathrm{N}$. This difference may represent nuance to the general theory that $\mathrm{N}$ concentrations increase due to biological $\mathrm{N}_{2}$ fixation. Increases in $\mathrm{NO}_{3}^{-}$-related metrics of $\mathrm{N}$ availability also suggest that the $\mathrm{N}$ cycle may become more "leaky" as secondary forests grow, because $\mathrm{NO}_{3}^{-}$and its derivatives can be lost via denitrification or leaching (Elser 2011).

A leaky $\mathrm{N}$ cycle is consistent with longstanding concepts of mature tropical forest ecosystems as relatively N-rich and P-poor (Vitousek 1984, Brookshire et al. 2011). Yet, what accounts for the increase in total $P$ in the top $20 \mathrm{~cm}$ of soil during secondary succession that is commonly observed (e.g., Fig. 2)? Because P is a rockderived nutrient, de novo inputs of $\mathrm{P}$ should be negligible in the absence of high dust deposition rates. A recent global meta-analysis of soil $\mathrm{P}$ responses to afforestation 
TABle 2. $\quad P$ values (Type II Wald chi-square test) associated with generalized mixed models testing how site characteristics are associated with the nine metrics of nutrient availability that changed during secondary succession.

\begin{tabular}{|c|c|c|c|c|}
\hline $\begin{array}{c}\text { Nutrient } \\
\text { metric }\end{array}$ & $\begin{array}{l}\text { Mean annual } \\
\text { temperature }\end{array}$ & $\begin{array}{l}\text { Mean annual } \\
\text { precipitation }\end{array}$ & $\begin{array}{l}\text { Disturbance } \\
\text { classification }\end{array}$ & $\begin{array}{c}\text { Soil } \\
\text { order }\end{array}$ \\
\hline Total N & 0.34 & 0.64 & 0.73 & 0.47 \\
\hline Total $\mathrm{P}_{\dagger}$ & 0.87 & $<0.01$ & $<0.01$ & $<0.01$ \\
\hline Nitrate & 0.73 & 0.26 & $<0.01$ & 0.40 \\
\hline Inorganic $\mathrm{N}$ & 0.25 & 0.31 & 0.10 & 0.31 \\
\hline $\mathrm{N}$ gas loss & 0.19 & 0.83 & NA & 0.56 \\
\hline Root N & 0.46 & 0.55 & 0.03 & 0.55 \\
\hline Litter mass: $\mathrm{N}$ & 0.38 & 0.25 & NA & 0.70 \\
\hline Foliar N:P† & 0.28 & NA & 0.11 & 0.03 \\
\hline Foliar $\delta^{15} \mathrm{~N} \dagger$ & $<0.01$ & NA & $<0.01$ & $<0.01$ \\
\hline
\end{tabular}

Notes: NA indicates "Not available" and represents situations when the characteristic was either dropped from the full model due to insufficient levels or the individual models failed to converge. Disturbance classifications included farmland (without mention of fire), agriculture with fire, timber harvest, and major wind events. Relationships between site characteristics and metrics of nutrient availability are shown Fig. 4. $P$ values less than 0.05 are bolded.

$\dagger$ Indicates full generalized mixed model structure was used (all site characteristics combined as fixed effects, study as random effect).
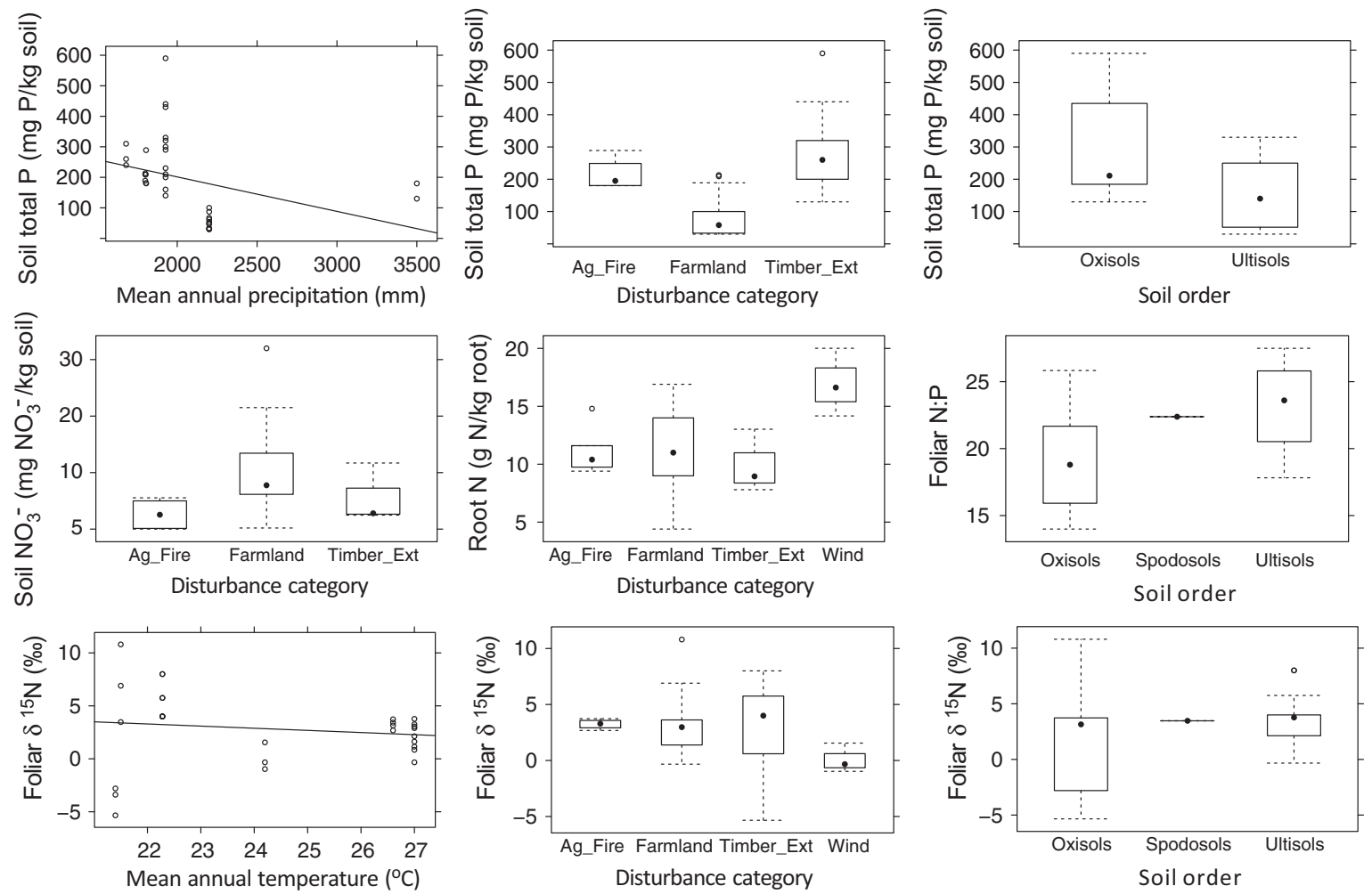

FIG. 5. Relationships between soil nutrients, including soil phosphorus (P), soil nitrate (NO3-), root nitrogen (N), foliar N:P, and foliar $\mathrm{N}$ isotope values $\left(\delta^{15} \mathrm{~N}\right)$, and site characteristics among secondary tropical forest chronosequences. Site characteristics included mean annual precipitation (MAP), mean annual temperature (MAT), soil order, and disturbance history categories (divided into agriculture with a history of fire [Ag_Fire], agriculture with no use of fire noted [Farmland], timber extraction and logging [Timber_Ext], and wind). MAP and MAT are presented as continuous variables, though they were largely constrained within chronosequences and therefore appear categorical in the figures. The box mid line represents the median; the box edges represent the 25th and 75th percentiles of the data. The upper whiskers are calculated as the smaller value between the maximum $y$-value or 1.5 times the interquartile range. The bottom whiskers are calculated as the larger value between the $y$-value and 1.5 times the interquartile range.

suggested that low-latitude ecosystems actually experience a decline in soil total $\mathrm{P}$ but an increase in labile $\mathrm{P}$ (Deng et al. 2017). It is important to note, however, that the meta-analysis by Deng et al. (2017) focused on studies of forested and disturbed sites and less on trajectories of nutrients during secondary succession. In the present study, it is unlikely that $\mathrm{P}$ accumulated during secondary succession. Rather, it is possible that soil $\mathrm{P}$ 
content in the surface soil increased via $\mathrm{P}$ translocation from deep in the soil profile to the surface soil. Soil P can move vertically in the soil profile during secondary succession (Jobbágy and Jackson 2001, Nepstad et al. 2001, MacDonald et al. 2012), resulting in depleted soil $\mathrm{P}$ pools at greater depths within a soil profile. In addition to vertical redistribution of soil $\mathrm{P}$, slowly cycling $\mathrm{P}$ fractions can decrease and produce more rapidly cycling labile P, even in highly weathered soils (Richter et al. 2006). Unfortunately, few studies in secondary tropical forest have considered how $\mathrm{P}$ availability changes with soil depth and we were unable to explore this possibility in our analysis. Ultimately, an increase in surface soil total $\mathrm{P}$ during secondary succession does not always translate to a net increase in soil labile $\mathrm{P}$, as we found no consistent evidence for a change in soil labile P. Labile P may be absorbed into plant or microbial biomass and changes in soil $\mathrm{P}$ fractions may not result in an accumulation of phosphate in the surface soil.

Some metrics of plant $\mathrm{N}$ mirrored the observed increases in soil N. However, plant material did not show a substantial change in $\mathrm{P}$ concentrations, though there were no reported increases in foliar $\mathrm{P}$ change during secondary succession in any site in the database (Fig. 3). Unfortunately, there were too few data available with which to make inferences for other plant tissues like root P or litter P. The increase in foliar N:P (Fig. 2) was consistent with the long-standing biogeochemical hypothesis that $\mathrm{P}$ supply to plants decreases relative to $\mathrm{N}$ during secondary succession in lowland wet tropical forest. However, given strong evidence of increases in other metrics of foliar $\mathrm{N}$ availability (foliar $\delta^{15} \mathrm{~N}$, litter mass : $\mathrm{N}$, and $\operatorname{root} \mathrm{N}$ ), increases in ecosystem $\mathrm{N}$ availability likely contributed to the widening foliar N:P ratio, even if increases in foliar $\mathrm{N}$ content (per unit biomass) were not detectable.

Shifts in plant community composition during succession are likely both a response to, and a cause of, concurrent changes in soil nutrient availability. A recent model analysis demonstrated that the resilience of tropical forest to climate-change type disturbance may depend on plant trait diversity (Sakschewski et al. 2016), which could reflect the influence of plant traits on biogeochemical cycling (Soper et al. 2018). As community composition transitions toward that of a mature forest during secondary succession (Peña-Claros 2003, Chazdon 2014), plant nutrient acquisition strategies may also shift to favor new biogeochemical conditions, such as a more $\mathrm{NO}_{3}^{-}$-dominated $\mathrm{N}$ cycle. For example, the decline in litter mass: $\mathrm{N}$ during secondary succession is consistent with the notion that plants may resorb less $\mathrm{N}$ prior to abscission late in succession than early in succession, before $\mathrm{N}$ capital has been restored by $\mathrm{N}_{2}$ fixation (Batterman et al. 2013). Plant traits such as litter chemistry can shape local biogeochemical cycling rates by influencing processes including decomposition and mineralization (Osborne et al. 2017, Soper et al. 2018). Increasing foliar $\delta^{15} \mathrm{~N}$ during secondary succession could be the product of numerous processes, but is consistent with fractionation of the soil $\mathrm{N}$ pool associated with increased soil $\mathrm{N}$ gas loss (Houlton et al. 2006), as we observed, and with declining symbiotic $\mathrm{N}_{2}$ fixation inputs during secondary succession (Barron et al. 2011, Batterman et al. 2013, Sullivan et al. 2014) that may be associated with down-regulation of $\mathrm{N}_{2}$ fixation in facultative species with increasing soil $\mathrm{N}$ availability.

By contrast, changes in plant community composition and plant traits may explain why foliar $\mathrm{P}$ did not significantly change in our study despite the increase in total $\mathrm{P}$ in surface soil. While soil and foliar P can be correlated at large spatial scales (Alvarez-Clare and Mack 2011), at small scales, foliar P and foliar N:P can be strongly governed by phylogenetics and species-level traits rather than just changes in soil $\mathrm{P}$ content alone (sensu lato Townsend et al. 2007, Ostertag 2010, Asner et al. 2014). Soil labile $\mathrm{P}$, which did not significantly change through succession in this analysis, appears to be more strongly associated with $\mathrm{P}$ limitation of individual species than communities (Alvarez-Clare et al. 2013, Turner et al. 2018). Consequently, foliar $\mathrm{P}$ may be more sensitive to species composition and plant traits than soil total $\mathrm{P}$. Foliar P content may simply decline as ruderal species give way to plants with lower relative $\mathrm{P}$ demand (Turner et al. 2018). Cecropia, a common early successional genus, has relatively high foliar $\mathrm{P}$ concentrations (Raaimakers et al. 1995), but late successional tree species often have lower P content than early successional species (Bahar et al. 2017). Changes in soil biogeochemical recuperation during secondary succession may change concurrently with the species composition of aggrading forests or biogeochemical recuperation may induce species shifts by favoring plant species that are best suited to new biogeochemical conditions. Either way, the above- and belowground biogeochemical characteristics of a regenerating forest approach those of mature forest during the first $100 \mathrm{yr}$ of secondary succession.

Unfortunately, we were unable to address possible changes in soil and plant $\mathrm{N}$ and $\mathrm{P}$ stocks during succession. Other studies that have analyzed temporal changes in $\mathrm{C}$ and $\mathrm{N}$ stocks have demonstrated the important role of bulk density, including changes in bulk density with soil depth through time, in mediating the change in elements (e.g., Murty et al. 2002). Reductions in soil bulk density during secondary succession (e.g., via increased root biomass, root turnover, or organic matter inputs) could mute increases in soil nutrient concentrations by reducing the soil stock. However, among the handful of studies in our database that reported bulk density, we found no clear evidence that soil bulk density changed consistently during succession: Three studies reported a decline in soil bulk density during secondary succession (Aweto 1981, Rasiah et al. 2004, Zangaro et al. 2008), four found little change once forests were established (Werner 1984, Brown and Lugo 1990, Reiners et al. 1994, Markewitz et al. 2004), and two studies reported a 
slight increase in bulk density, which would increase the effect of nutrient concentration on nutrient stocks (Erickson et al. 2001, Templer et al. 2005). It is also possible that changes in soil bulk density can occur shortly after agricultural abandonment (e.g., Keller and Reiners 1994) rather than during forest succession. Together, these patterns suggest that changes in soil bulk density likely do not confound the concentration-based biogeochemical changes we observed here. We encourage subsequent successional studies of soil biogeochemistry in the tropics to integrate soil bulk density into analyses in order to better characterize change in whole ecosystem nutrient stocks.

The consistent rates of change of nutrient metrics (Fig. 2) may be particularly useful for developing models of biogeochemical change during secondary succession in this biome. The nine biogeochemical metrics that recuperated during secondary succession were apparent despite substantial species diversity, different initial nutrient availability at the outset of succession, and variation in disturbance history, soils, climate, and many other factors among the study sites (Table 2). Though we were unable to directly relate biogeochemical recuperation to species diversity, the sites in this analysis span a wide biogeographic range of the lowland tropical forest biome (Fig. 1). Clearly, even as recuperating sites generally behave similarly, some chronosequences do not, (Figs. 2, 3) and both the biogeochemical patterns and the causes of those patterns should not be ignored. Yet, even when metrics did not shift significantly with succession (e.g., nitrification, $\mathrm{N}$ mineralization, litter $\mathrm{N}$ : $\mathrm{P}$, and foliar $\mathrm{P}$ ), this usually reflected consistently low rates of change rather than the effect of large variance among studies. As evidence, variance in GLMM parameter coefficients was relatively small and slopes tended to have the similar direction among studies (Table 1, Fig. 3). Further, several of the metrics that did have substantial model variation had only one or two outlier studies with a substantially different rate of change from the rest of the studies. This finding was supported by the relatively small influence of climate, disturbance history, and soils on the rate of change among sites (Table 2). With the exception of foliar $\delta^{15} \mathrm{~N}$ and soil total $\mathrm{P}$ (Table 2; Fig. 5), most recuperating nutrient metrics were only modestly influenced by variation in ecosystem state factors. This trend suggests that $\mathrm{N}$ recuperation, likely driven by symbiotic and free-living $\mathrm{N}_{2}$ fixation (Sullivan et al. 2014), may be common across the lowland tropics despite wide variations in $\mathrm{N}_{2}$-fixing legume abundance among sites (Losos and Leigh 2004) and the lower abundance of legumes in moist and wet forest relative to dry forest (Gei et al. 2018). However, soil order can significantly influence soil carbon change during secondary succession in tropical forest (e.g., Powers et al. 2011, Marín-Spiotta and Sharma 2013), and this pattern could be expected for $\mathrm{N}$ and $\mathrm{P}$ as well. The dominance of highly weathered Oxisol and Ultisol soils in our data set may have statistically limited our ability to partition differences due to soil order, but Oxisols and Ultisols are common in the lowland tropical region. These results identify a need to quantify changes in nutrient cycling during secondary succession under a variety of state factors (e.g., topography; Osborne et al. 2017) in lowland tropical forest.

Our results also suggest that, over time, nutrient cycles in secondary lowland tropical forest become increasingly similar to those in mature forest (Fig. 4). Of the nine nutrient cycling metrics that recuperated during secondary succession, the rate of change of eight metrics did not differ, regardless of whether mature forest was included or not. Additionally, several of the metrics had higher variance in the estimated rate of change when mature forest was excluded (Fig. 4), indicating that while mature forest does not change the trajectory of recuperation, it may have an important role in attenuating the variance in calculated recuperation rates. We suggest that future secondary tropical forest chronosequence studies should include mature forest in their experimental design and consider mature forest as a continuation of the chronosequence, not as a distinct reference condition.

We acknowledge that comparing rates of change of metrics of $\mathrm{N}$ and $\mathrm{P}$ availability with and without mature forest is based on assumptions of the age of mature forest, which in many cases is challenging to estimate and is likely to vary among sites. While the average age of a forest may be substantially younger than the oldest tree or the time since the last stand-scale disturbance (Hartshorn 1980), we tested whether our results were simply an artifact of our assumption that mature forest was $100 \mathrm{yr}$ old. We reran the GLMMs assuming a 200-yr mature forest age and found nearly identical results: of the 23 nutrient metrics, 22 had similar results with 200 -yr mature forest as $100 \mathrm{yr}$ mature forest. Only foliar $\delta^{15} \mathrm{~N}$ had substantially different results between the different mature forest ages $(P=0.076$ at $100 \mathrm{yr}, P=0.813$ at $200 \mathrm{yr})$. Overall, these results indicate that the trends we observed here are robust regardless of the precise average age of mature forest. Given frequent small-scale disturbances in mature forest, our analysis suggests that there is not a sharp biogeochemical boundary between late secondary forest and patchy mature forest and that secondary succession does not lead to an alternative biogeochemical state.

While our results suggest that biogeochemical recuperation occurs in a similar manner across a range of secondary forests throughout the lowland tropics, it is possible that repeated forest clearing and regrowth cycles could hinder the ability of nutrient cycles to recover in the future. For example, while the length of time that recovering forest sites in our study were exposed to prior anthropogenic land use varied in our analysis, very few of the studies included sites with a history of multiple disturbances and recovery cycles prior to the study period (but see Robertson 1984, Gehring et al. 2005, Liu et al. 2012). However, Zarin et al. (2005) demonstrated 
that rates of regrowth of secondary forests in the Amazon region declined with increasing numbers of previous fires for pasture or agricultural management prior to abandonment. This may, at least in part, reflect the negative effects of repeated disturbance on the nutrient cycles. Thus, while the results of the present study demonstrate the natural potential of biogeochemistry to recover in secondary tropical forest, the degree to which rates of biogeochemical recuperation are affected by multiple prior disturbances is still unclear.

The generally consistent biogeochemical changes in the nine metrics of nutrient availability we observed were remarkable given the profound physical, biogeochemi$\mathrm{cal}$, and biological heterogeneity of tropical forest, and provide new insight to decades of debate about the role of nutrient cycling during forest succession in the tropics (Jordan and Herrera 1981). Changes in biogeochemical metrics through time and across the landscape may help explain tropical forest biomass resilience to disturbance (Poorter et al. 2016). The apparent biogeochemical recovery of secondary forest also provides a strong incentive to conserve regrowing forests to support the productivity and nutrient cycling of tropical ecosystems (Lamb et al. 2005) and promote the redevelopment of mature forest. While mid- and late-successional forests are common in temperate regions, they are still relatively rare in the tropics, because they are often cleared repeatedly for agriculture (Neeff et al. 2006, de Almeida et al. 2010). Regardless, if historical land use trends in the tropics persist, the extent and biological importance of secondary forest will increase. Our results suggest that biogeochemical recuperation is common among the secondary forests studied to date. Although more study is needed on biogeochemical recuperation in more severely impacted sites, our study indicates that the productivity of secondary forest can often be sustained by the consistent change in soil nutrients and plant nutritional needs during secondary forest succession.

\section{ACKNOWLEDGMENTS}

C. C. Cleveland acknowledges support from the National Science Foundation (DEB - 1556643), and E. A. Davidson and R. L. Nifong acknowledge support from the National Science Foundation (DEB - 1457017). We thank A. Myers for assistance with production of Figure 1 and several anonymous reviewers for their suggestions.

\section{Literature Cited}

Alvarez-Clare, S., and M. C. Mack. 2011. Influence of precipitation on soil and foliar nutrients across nine Costa Rican forests. Biotropica 43:433-441.

Alvarez-Clare, S., M. C. Mack, and M. Brooks. 2013. A direct test of nitrogen and phosphorus limitation to net primary productivity in a lowland tropical wet forest. Ecology 94:1540-1551.

Asner, G. P., R. E. Martin, R. Tupayachi, C. B. Anderson, F. Sinca, L. Carranza-Jiménez, and P. Martinez. 2014. Amazonian functional diversity from forest canopy chemical assembly. Proceedings of the National Academy of Sciences USA 111:5604-5609.

Aweto, A. O. 1981. Secondary succession and soil fertility restoration in south-western Nigeria: II Soil fertility restoration. Journal of Ecology 69:609-614.

Bahar, N. H. A., et al. 2017. Leaf-level photosynthetic capacity in lowland Amazonian and high-elevation Andean tropical moist forests of Peru. New Phytologist 214:1002-1018.

Barron, A. R., D. W. Purves, and L. O. Hedin. 2011. Facultative nitrogen fixation by canopy legumes in a lowland tropical forest. Oecologia 165:511-520.

Bates, D., M. Maechler, B. Bolker, and S. Walker. 2015. Fitting linear mixed-effects models using lme4. Journal of Statistical Software 67:1-48.

Batterman, S. A., L. O. Hedin, M. van Breugel, J. Ransijn, D. J. Craven, and S. J. Hall. 2013. Key role of symbiotic dinitrogen fixation in tropical forest secondary succession. Nature 502:224-227.

Brookshire, E. N. J., S. Gerber, D. N. L. Menge, and L. O. Hedin. 2011. Large losses of inorganic nitrogen from tropical rainforests suggest a lack of nitrogen limitation. Ecology Letters 15:9-16.

Brown, S., and A. E. Lugo. 1990. Effects of forest clearing and succession on the carbon and nitrogen content of soils in Puerto Rico and US Virgin Islands. Plant and Soil 124:53-64.

Chazdon, R. L. 2014. Second growth: the promise of tropical forest regeneration in an age of deforestation. University of Chicago Press, Chicago, Illinois, USA.

Clark, D. B. 1996. Abolishing virginity. Journal of Tropical Ecology 12:735-739.

Cleveland, C. C., and A. R. Townsend. 2006. Nutrient additions to a tropical rain forest drive substantial soil carbon dioxide losses to the atmosphere. Proceedings of the National Academy of Sciences USA 103:10316-10321.

Cleveland, C. C., et al. 2011. Relationships among net primary productivity, nutrients and climate in tropical rain forest: a pan-tropical analysis. Ecology Letters 14:1313-1317.

Cleveland, C. C., et al. 2015. A comparison of plot-based, satellite, and Earth system model estimates of tropical forest net primary production. Global Biogeochemical Cycles 29:626644.

Davidson, E. A., et al. 2004. Nitrogen and phosphorus limitation of biomass growth in a tropical secondary forest. Ecological Applications 14:S150-S163.

Davidson, E. A., et al. 2007. Recuperation of nitrogen cycling in Amazonian forests following agricultural abandonment. Nature 447:995-998.

Davidson, E. A., D. Markewitz, R. D. O. Figueiredo, and P. B. D. Camargo. 2018. Nitrogen fixation inputs in pasture and early successional forest in the Brazilian Amazon region: evidence from a claybox mesocosm study. Journal of Geophysical Research: Biogeosciences, 123:712-721.

de Almeida, A. S., T. A. Stone, I. C. G. Vieira, and E. A. Davidson. 2010. Non-frontier deforestation in the eastern Amazon. Earth Interactions 14:1-15.

Delignette-Muller, M. L., and C. Dutang. 2015. fitdistrplus: an $\mathrm{R}$ package for fitting distributions. Journal of Statistical Software 64:1-34.

Deng, Q., D. E. McMahon, Y. Xiang, C.-L. Yu, R. B. Jackson, and D. Hui. 2017. A global meta-analysis of soil phosphorus dynamics after afforestation. New Phytologist 213:181-192.

Elser, J. J. 2011. A world awash with nitrogen. Science 334:1504-1505.

Erickson, H., M. Keller, and E. A. Davidson. 2001. Nitrogen oxide fluxes and nitrogen cycling during postagricultural 
succession in forest fertilization in the humid tropics. Ecosystems 4:67-84.

FAO. 2016. State of the world's forests 2016-forests and agriculture: land-use challenges and opportunities. Food and Agriculture Organization of the United Nations, Rome, Italy.

Gehring, C., P. L. G. Vlek, L. A. G. de Souza, and M. Denich. 2005. Biological nitrogen fixation in secondary regrowth and mature rainforest in central Amazonia. Agriculture Ecosystems \& Environment 111:237-252.

Gei, M., et al. 2018. Legume abundance along successional and rainfall gradients in Neotropical forests. Nature Ecology \& Evolution 2:1104-1111.

Hansen, M. C., et al. 2013. High-resolution global maps of $21^{\text {st }}$-century forest cover change. Science 342:850-853.

Hart, S. C., J. M. Stark, E. A. Davidson, and M. K. Firestone. 1994. Nitrogen mineralization, immobilization, and nitrification. Pages 985-1018 in R. W. Weaver, editor. Methods of soil analysis, part 2: microbiological and biochemical properties. Soil Science Society of America, Madison, Wisconsin, USA.

Hartshorn, G. S. 1980. Neotropical forest dynamics. Biotropica 12:23-30.

Hedin, L. O., P. M. Vitousek, and P. A. Matson. 2003. Nutrient losses over four million years of tropical forest development. Ecology 84:2231-2255.

Holdridge, L. R., W. C. Grenke, W. H. Hatheway, T. Liang, and J. A. Tosi. 1971. Forest environments in tropical life zones: a pilot study. Pergamon Press, Oxford, UK.

Houlton, B. Z., D. M. Sigman, and L. O. Hedin. 2006. Isotopic evidence for large gaseous nitrogen losses from tropical rainforests. Proceedings of the National Academy of Sciences USA 103:8745-8750.

Huang, W., J. Liu, G. Zhou, D. Zhang, and Q. Deng. 2011. Effects of precipitation on soil acid phosphatase activity in three successional forests in Southern China. Biogeosciences 8:1901-1910.

Huang, W. J., G. Y. Zhou, and J. X. Liu. 2012. Nitrogen and phosphorus status and their influence on aboveground production under increasing nitrogen deposition in three successional forests. Acta Oecologia 44:20-27.

Huang, W., J. Liu, Y. P. Wang, G. Zhou, T. Hang, and Y. Li. 2013. Increasing phosphorus limitation along three successional forests in southern China. Plant and Soil 364:181-191.

Jenny, H. 1941. Factors of soil formation. McGraw Hill, New York, New York, USA.

Jenny, H. 1950. Causes of the high nitrogen and organic matter content of certain tropical forest soils. Soil Science 69:63-70.

Jobbágy, E. G., and R. B. Jackson. 2001. The distribution of soil nutrients with depth: global patterns and the imprint of plants. Biogeochemistry 53:51-77.

Johnson, E. A., and K. Miyanishi. 2008. Testing the assumptions of chronosequences in succession. Ecology Letters 11:419-431.

Jordan, C. F., and R. Herrera. 1981. Tropical rain forests: are nutrients really critical? American Naturalist 117:167-180.

Jordan, C., et al. 1983. Nitrogen dynamics during conversion of primary Amazonian rain forest to slash and burn agriculture. Oikos 40:131-139.

Keller, M., and W. A. Reiners. 1994. Soil-atmosphere exchange of nitrous oxide, nitric oxide, and methane under secondary succession of pasture to forest in the Atlantic lowlands of Costa Rica. Global Biogeochemical Cycles 8:399-409.

Lamb, D., P. D. Erskine, and J. A. Parrotta. 2005. Restoration of degraded tropical forest landscapes. Science 310:16281632.

Lawrence, D., and K. Vandecar. 2015. Effects of tropical deforestation on climate and agriculture. Nature Climate Change $5: 27-36$.
Liu, F. M., et al. 2012. Leaf functional traits and trait relationships of tropical woody vegetation in relation to successional stage: shifts in understory and canopy layers. Ecoscience 19:198-208.

Liu, Y. Y., et al. 2015. Recent reversal in loss of global terrestrial biomass. Nature Climate Change 5:470-474.

Lohbeck, M., L. Poorter, M. Martínez-Ramos, and F. Bongers. 2015. Biomass is the main driver of changes in ecosystem process rates during tropical forest succession. Ecology 69:12421252 .

Long, W., X. Yang, and D. Li. 2012. Patterns of species diversity and soil nutrients along a chronosequence of vegetation recovery in Hainan Island, South China. Ecological Restoration 27:561-568.

Losos, E. C., and E. G. Leigh. 2004. Tropical forest diversity and dynamism. University of Chicago Press, Chicago, Illinois, USA.

MacDonald, G. K., E. M. Bennett, and Z. E. Taranu. 2012. The influence of time, soil characteristics, and land-use history on soil phosphorus legacies: a global meta-analysis. Global Change Biology 18:1904-1917.

Marín-Spiotta, E., and S. Sharma. 2013. Carbon storage in successional and plantation forest soils: a tropical analysis. Global Ecology and Biogeography 22:105-117.

Markewitz, D., E. A. Davidson, P. Moutinho, and D. Nepstad. 2004. Nutrient loss and redistribution after forest clearing on a highly weathered soil in Amazonia. Ecological Applications 14:S177-S199.

McGrath, D. A., C. K. Smith, H. L. Gholz, and F. de Assis Oliveira. 2001. Effects of land-use change on soil nutrient dynamics in Amazônia. Ecosystems 4:625-645.

McGroddy, M. E., T. Daufresne, and L. O. Hedin. 2004. Scaling of C:N: P stoichiometry in forests worldwide: implications of terrestrial Redfield-type ratios. Ecology 85:2390-2401.

Mo, J., S. Brown, S. Peng, and G. Kong. 2003. Nitrogen availability in disturbed, rehabilitated and mature forests of tropical China. Forest Ecology and Management 175:573-583.

Mora, F., M. Marínez-Ramos, G. Ibarra-Manríquez, A. PérezJiménez, J. Trilleras, and P. Balvanera. 2015. Testing chronosequences through dynamic approaches: time and site effects on tropical dry forest succession. Biotropica 47:38-48.

Murty, D., M. U. F. Kirschbaum, R. E. McMurtrie, and H. McGilvray. 2002. Does conversion of forest to agricultural land change soil carbon and nitrogen? A review of the literature. Global Change Biology 8:105-123.

Nagy, C. R., E. B. Rastetter, C. Neill, and S. Porder. 2017. Nutrient limitation in tropical secondary forests following different management practices. Ecological Applications 27:734-755.

Neeff, T., R. M. Lucas, J. R. dos Santos, E. S. Brondizio, and C. C. Freitas. 2006. Area and age of secondary forests in Brazilian Amazonia 1978-2002: an empirical estimate. Ecosystems 9:609-623.

Neill, C., L. A. Deegan, S. M. Thomas, and C. C. Cerri. 2001. Deforestation for pasture alters nitrogen and phosphorus in small Amazonian streams. Ecological Applications 11:18171828.

Nepstad, D., P. R. S. Moutinho, and D. Markewitz. 2001. The recovery of biomass, nutrient stocks, and deep soil functions in secondary forests. Pages 139-155 in E. McClain, R. Victoria, and J. E. Riche, editors. The biogeochemistry of the Amazon basin. Oxford University Press, New York, New York, USA.

Norden, N., et al. 2015. Successional dynamics in Neotropical forests are as uncertain as they are predictable. Proceedings of the National Academy of Sciences USA 112:8013-8018.

Odum, E. P. 1969. The strategy of ecosystem development. Science 164:262-270. 
Osborne, B. B., M. K. Nasto, G. P. Asner, C. S. Balzotti, C. C. Cleveland, B. W. Sullivan, P. G. Taylor, A. R. Townsend, and S. Porder. 2017. Climate, topography, and canopy chemistry exert hierarchical control over soil $\mathrm{N}$ cycling in a Neotropical lowland forest. Ecosystems 20:1089-1103.

Ostertag, R. 2010. Foliar nitrogen and phosphorus accumulation responses after fertilization: an example from nutrientlimited Hawaiian forests. Plant and Soil 334:85-98.

Pan, Y., et al. 2011. A large and persistent carbon sink in the world's forests. Science 333:988-993.

Peltzer, D. A., et al. 2010. Understanding ecosystem retrogression. Ecological Monographs 80:509-529.

Peña-Claros, M. 2003. Changes in forest structure and species compositions during secondary forest succession in the Bolivian Amazon. Biotropica 35:450-461.

Poorter, L., et al. 2016. Biomass resilience of Neotropical secondary forests. Nature 530:211-214.

Porder, S., and G. E. Hilley. 2011. Linking chronosequences with the rest of the world: predicting soil phosphorus content in denuding landscapes. Biogeochemistry 102:153-166.

Powers, J. S., and E. Marín-Spiotta. 2017. Ecosystem processes and biogeochemical cycles in secondary tropical forest succession. Annual Review of Ecology, Evolution, and Systematics 48:497-519.

Powers, J. S., M. D. Corre, T. E. Twine, and E. Veldkamp. 2011. Geographic bias of field observations of soil carbon stocks with tropical land-use changes precludes spatial extrapolation. Proceedings of the National Academy of Sciences USA 108:6318-6322.

R Core Team. 2017. R: a language and environment for statistical computing. R Foundation for Statistical Computing, Vienna, Austria. https://www.R-project.org/

Raaimakers, D., R. G. A. Boot, P. Dijkstra, S. Pot, and T. Pons. 1995. Photosynthetic rates in relation to leaf phosphorus content in pioneer versus climax tropical rainforest trees. Oecologia 102:120-125.

Ramankutty, N., H. K. Gibbs, F. Achard, R. Defries, J. A. Foley, and R. A. Houghton. 2007. Challenges to estimating carbon emissions from tropical deforestation. Global Change Biology 13:51-66.

Rasiah, V., S. K. Florentine, B. L. Williams, and M. E. Westbrooke. 2004. The impact of deforestation and pasture abandonment on soil properties in the wet tropics of Australia. Geoderma 120:35-45.

Reiners, W. A., A. F. Bouwman, W. F. J. Parsons, and M. Keller. 1994. Tropical rain forest conversion to pasture: changes in vegetation and soil properties. Ecological Applications 4:363377.

Richter, D. D., H. L. Allen, J. Li, D. Markewitz, and J. Raikes. 2006. Bioavailability of slowly cycling soil phosphorus: major restructuring of soil $\mathrm{P}$ fractions over four decades in an aggrading forest. Oecologia 150:259-271.

Robertson, G. P. 1984. Nitrification and nitrogen mineralization in a lowland rainforest succession in Costa Rica, Central America. Oecologia 61:99-104.

Sakschewski, B., et al. 2016. Resilience of Amazon forests emerges from plant trait diversity. Nature Climate Change 6:1032-1036.
Soil Survey Staff. 2014. Keys to soil taxonomy. Twelfth edition. USDA Natural Resources Conservation Service, Washington, D.C., USA.

Soper, F. M., et al. 2018. Remotely sensed canopy nitrogen influences $\mathrm{N}_{2} \mathrm{O}$ emissions in a lowland tropical rainforest. Ecology 99:2080-2089.

Sullivan, B. W., et al. 2014. Spatially robust estimates of biological nitrogen $(\mathrm{N})$ fixation imply substantial human alteration of the tropical $\mathrm{N}$ cycle. Proceedings of the National Academy of Sciences USA 111:8101-8106.

Taylor, P. G., et al. 2017. Temperature and rainfall interact to control carbon cycling in tropical forests. Ecology Letters 20:779-788.

Templer, P. H., P. M. Groffman, A. S. Flecker, and A. G. Power. 2005. Land use change and soil nutrient transformations in the Los Haitises region of the Dominican Republic. Soil Biology and Biochemistry 37:215-225.

Townsend, A. R., C. C. Cleveland, G. P. Asner, and M. M. C. Bustamante. 2007. Controls over foliar N: P ratios in tropical rain forests. Ecology 88:107-118.

Townsend, A. R., G. P. Asner, and C. C. Cleveland. 2008. The biogeochemical heterogeneity of tropical forests. Trends in Ecology and the Environment 23:424 431.

Turner, B. L., T. Brenes-Arguedas, and R. Condit. 2018. Pervasive phosphorus limitation of tree species but not communities in tropical forests. Nature 555:367-370.

Uhl, C. 1987. Factors controlling succession following slashand-burn agriculture in Amazonia. Journal of Ecology 75:377-407.

Vitousek, P. M. 1984. Litterfall, nutrient cycling, and nutrient limitation in tropical forests. Ecology 65:285-298.

Vitousek, P. M., and W. A. Reiners. 1975. Ecosystem succession and nutrient retention: a hypothesis. BioScience 25:376-381.

Vitousek, P. M., P. A. Matson, and K. Van Cleve. 1989. Nitrogen availability and nitrification during succession: primary, secondary, and old-field series. Plant and Soil 115:229-239.

Walker, T. W., and J. K. Syers. 1976. The fate of phosphorus during pedogenesis. Geoderma 15:1-19.

Walker, L. R., D. A. Wardle, R. D. Bardgett, and B. D. Clarkson. 2010. The use of chronosequences in studies of ecological succession and soil development. Journal of Ecology 98:725-736.

Werner, P. 1984. Changes in soil properties during tropical wet forest succession in Costa Rica. Biotropica 16:43-50.

Wieder, W. W., C. C. Cleveland, W. K. Smith, and K. ToddBrown. 2015. Future productivity and carbon storage limited by terrestrial nutrient availability. Nature Geoscience 8:441444.

Winbourne, J. B., A. Feng, L. Reynolds, D. Piotto, M. G. Hastings, and S. Porder. 2018. Nitrogen cycling during secondary succession in Atlantic Forest of Bahia, Brazil. Scientific Reports 8:1377.

Zangaro, W., et al. 2008. Changes in arbuscular mycorrhizal associations and fine root traits in sites under different plant successional phases in southern Brazil. Mycorrhiza 19:37-45.

Zarin, D. J., et al. 2005. Legacy of fire slows carbon accumulation in Amazonian forest regrowth. Frontiers in Ecology \& the Environment 3:365-369.

\section{SUPPORTING INFORMATION}

Additional supporting information may be found in the online version of this article at http://onlinelibrary.wiley.com/doi/ 10.1002/ecy.2641/suppinfo 